\title{
Hva kan forklare de høye selvmordsratene blant urfolksguttene?
}

\author{
Ved Anne Silviken
}

\begin{abstract}
Selvmord er et alvorlig samfunnsproblem blant mange urfolksgrupper, og det er spesielt blant de unge guttene at selvmordsratene er alarmerende høye. Denne kjønnsgradienten kan vitne om at urfolksguttene har vært mer sårbare enn jentene under de raske samfunnsmessige forandringene som følge av overgangen fra naturalhushold til pengehushold.
\end{abstract}

Artikkelen er skrevet med utgangspunkt i forskningsbasert litteratur av epidemiologisk karakter og relevant faglitteratur på området. Det er ikke søkt systematisk på referanser til denne artikkelen spesielt. Referansene har jeg ervervet gjennom mitt doktorgradsarbeid hvor temaet var selvmordsatferd blant samer i Nord-Norge. Innledningsvis i artikkelen vil jeg gjøre rede for utviklingen av de høye selvmordsratene blant urfolk sett i lys av raske samfunnsmessige endringer. Forskning viser at det primært er de yngre aldersgruppene som har høy dødelighet i selvmord og da spesielt guttene. I diskusjonsdelen vil jeg fokusere på betydningen av endringene i tradisjonelle kjønnsrollemønster og oppdragelsesverdier som mulige forklaringsfaktorer på de høye selvmordsratene blant unge urfolksgutter.

\section{Høye selvmordsrater blant urfolk}

Forekomsten av selvmord blant urfolk har endret seg fra å være et relative sjeldent femomen til å nå et epidemisk nivå i løpet av de siste 3-4 tiår (Bjerregaard \& Lynge, 2006; Leenaars, 2006). Den ekstreme $\varnothing$ kningen i selvmordsratene har vært sammenfallende med de raske samfunnsmessige endringene som mange urfolk har opplevd (Boothroyd et al., 2001; Hunter \& Harvey, 2002; Kirmayer, 1994). I Grønland begynte selvmordsraten å stige dramatisk fra 1970-tallet (ca. 13 per 100 000) og nådde en topp i 1986 med en rate på 125 per 100000 (Hicks, 2007). Selvmordsproblematikken blant urfolk kan forstås ut fra Durkheims teori som hevder at anomiske selvmord $\varnothing$ ker i løpet av perioder med sosiale forandringer (Davenport \& Davenport, 1987). Anomi i denne sammenheng viser til omstendigheter hvor forandringene i samfunnet finner sted for raskt, noe som fører til avvisning av eksisterende normer før nye normer er akseptert og internalisert (BilleBrahe, 2002).

Et fellestrekk i mange urfolks historie er at deres kultur tidligere har vært fors $\varnothing \mathrm{kt}$

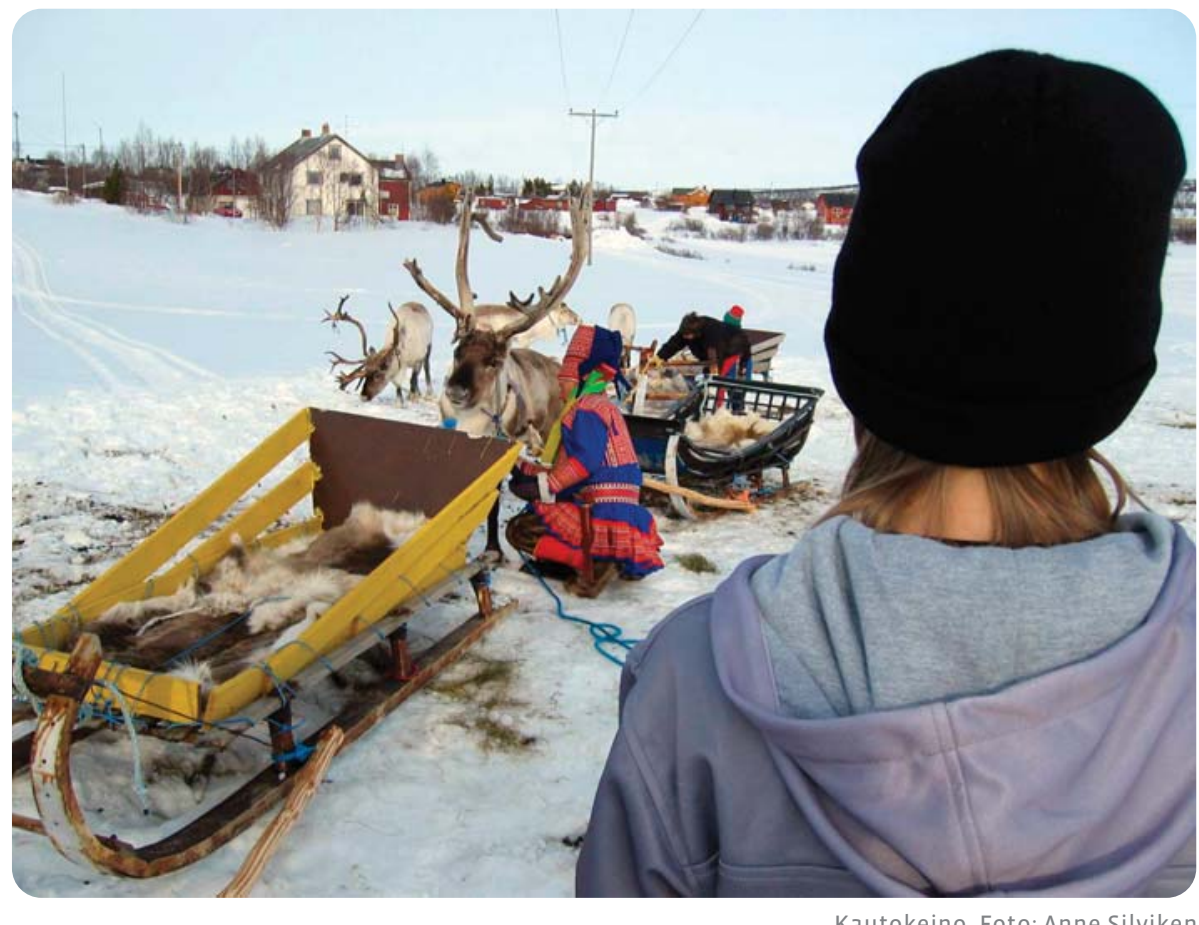

Kautokeino. Foto: Anne Silviken

undertrykt fra sentrale myndigheters side, og at urfolkene har vært utsatt for langvarig assimilasjonspolitikk (som for eksempel fornorskning). I tillegg til raske samfunnsmessige endringer har historiske og strukturelle faktorer som undertrykkelse av urfolks kultur og levesett, assimileringspolitikk og i nyere tid kulturell revitalisering hatt en viktig betydning for dagens sosio $\varnothing$ konomiske status og levekår blant urfolk. Disse forhold har forårsaket ulike betingelser for helse og samfunnsproblemer, som igjen får betydning for urfolksgruppenes respektive selvmordsrater. Den moderate selvmordsraten blant samer i Nord-Norge (i tidsperioden 1970 1998: 20 per 100000 person år (p.å.)) og den høye selvmordsraten i Grønland (100 per 100000 ) er et eksempel på hvor store forskjeller det er mellom urfolksgrupper (Hicks, 2007; Silviken, Haldorsen \& Kvernmo, 2006). Forekomsten av selvmord kan betraktes som en indikator på hvor store vansker som finnes i en urfolkspopulasjon (Kirmayer et al., 2000).
De raske samfunnsmessige endringene blant urfolk har blant annet ført til ustabilitet med alvorlige konsekvenser på gruppe- og individnivå, for eksempel dysfunksjonelle hjem som følge av $\varnothing \mathrm{kt}$ alkoholforbruk og vold i nære relasjoner, psykiske plager og høy forekomst av kriminalitet (Hunter \& Milroy, 2006; Young, 1994). En annen faktor som har bidratt til dårligere foreldreskap blant urfolk er den utstrakte bruken av internatskoler, en av mange strategier som ble brukt i den påtvungne assimileringspolitikken overfor de fleste urfolk i den vestlige verden.

Ifølge Hunter og Milroy var barna de mest sårbare i forandringsprosessen av sosiale og familiære strukturer (2006). De som har tatt sitt eget liv blant urfolk i Kimberley, Australia, siden 1980-tallet, har vært tenåringer, barna av foreldre som opplevde de raske sosiale endringene som unge voksne og kommende foreldre (Hunter, 1999). Det som karakteriserte disse unge urfolkene, var at de tilhørte den første generasjonen som hadde vokst 
opp i samfunn og familier berørt av normativ ustabilitet.

Selvmordsstatistikken blant urfolk over hele verden viser at den raske $\varnothing$ kningen i selvmord som har funnet sted siden 1960-70-tallet, er mest uttalt blant gutter i aldersgruppen 15-24 år (Clarke, Frankish \& Green, 1997; Sigurdson et al., 1994; Bjerregaard \& Lynge, 2006;

Silviken, Haldorsen \& Kvernmo, 2006). I Grønland for eksempel, er raten blant unge gutter i alderen 15-24 år alarmerende høy (450 per 100,000 p.å.), mens raten for de grønlandske jentene i samme aldersgruppe er betydelig lavere (100. 150 per 100000 p.å.) (Bjerregaard \& Lynge, 2006). Et tilsvarende mønster fant man i en registerbasert studie blant samer i Nord-Norge hvor raten var spesielt høy blant de unge guttene sammenlignet med jentene (15-24 år) (53/100 000 vs 16/ 100000 p.å.) (Silviken et al., 2006). I enkelte urfolksgrupper i Nord-Amerika utgjorde selvmord blant gutter i alderen 15-34 år $64 \%$ av alle selvmord i tidsperioden 1979-1992 (Wallace et al., 1996). Det har i tillegg vært rapportert at unge urfolksgutter ikke bare har høye selvmordsrater, men at de også har en høy forekomst av selvmordsfors $\varnothing \mathrm{k}$ (Kirmayer et al., 1996, 1998).

$\varnothing$ kningen i selvmordsatferd blant unge urfolk kan i en viss grad forklares med den høye forekomsten av generelle risikofaktorer, slik som rusmisbruk, psykiske vansker, omsorgssvikt, seksuelle overgrep og vold i nære relasjoner. Men den dramatiske $\varnothing$ kningen i selvmord blant guttene kan ikke kun forklares med generelle risikofaktorer, da vi ikke ser en tilsvarende $\varnothing$ kning blant jentene. Hva er det som har skjedd i overgangen fra naturalhusholding til pengehushold som kan forklare de høyre selvmordsratene blant urfolksguttene? En av de mest sentrale problemstillingene innen suicidologien er å forstå hva som forårsaker kjønnsforskjellene i forekomsten av selvmordsatferd. Samfunnsmessige forhold knyttet til kjønnsroller og endringer i kjønnsroller er i denne sammenheng antatt å være den mest sannsynlige forklaringen (Hawton, 2000).
Hva kan forklare den høye forekomsten av selvmord blant unge urfolksgutter?

Selvmordsproblematikk er et komplekst fenomen med ulike årsakssammenhenger på individ- og samfunnsnivå. I denne artikkelen fokusere jeg på endringer i kjønnsrollem $\varnothing$ nster og betydningen av oppdragelsesverdier som noen mulige forklaringsfaktorer på de høye selvmordsratene blant de unge urfolksguttene.

\section{Endringer $i$ tradisjonelle kjønnsrollemønster}

Ifølge Kirmayer og kollegaer (1998, 2000) kan den høye forekomsten av selvmord blant urfolksgutter forklares med de store endringene i det tradisjonelle kjønnsrollem ønsteret som følge av raske samfunnsmessige endringer. Endringene i kjønnsrollem $\varnothing$ nsteret har resultert i grunnleggende problemer i forhold til identitet og selvfølelse, samt $\varnothing \mathrm{kt}$ sårbarhet for selvdestruktiv atferd blant guttene (Kirmayer et al., 1998, 2000). I likhet med majoritetsbefolkningen har urfolksgrupper hatt et tradisjonelt kjønnsrollemønster både i forhold til aktiviteter og verdier. Selv om overgangen fra tradisjonelt levesett (naturalhusholdning og primærnæringer) til et mer moderne vestlig levesett (pengehusholdning med sekundær- og tertiærnæringer) har påvirket begge kjønn, har endringene ber $\varnothing \mathrm{rt}$ guttenes kjønnsrollemønster mer gjennomgripende (Wexler, 2006). I de fleste urfolkssamfunn har det vært en omfattende endring i tradisjonell primærnæring slik som fiske, jakt og reindrift, næringer som hovedsakelig har vært dominert av menn. Et sitat fra en eldre Inupiat i nordvestAlaska illustrerer dette dilemmaet godt "Hva er igjen for disse unge menn til å føle seg som en mann? De var tradisjonelt den som tok ansvar for familien, nå er ting veldig forandret. De føler ikke lenger at de tar vare på familien. Naturalhusholdning er veldig viktig for at menn skal føle at de bidrar. Det gir dem en plass" (Wexler, 2006, s. 2943). Endringene i kjønnsrollem $\varnothing$ nsteret og/eller mangel på sosiale roller kan ha gjort guttene generelt sett mer sårbare for opplevelse av frustrasjon og meningsløshet, og på den måten $\varnothing \mathrm{kt}$ risikoen for rusmisbruk, depresjon, håpløshet og følelse av å være kulturelt fremmedgjort - alle velkjente risikofaktorer for selvmordsatferd. Urfolksjentene derimot har hatt mer kontinuitet i sine kjønnsroller med hensyn til det å føde barn, ha ansvar for barneoppdragelse og hushold. De raske samfunnsmessige endringene synes ikke å ha vært så gjennomgripende for jentene, noe som kan forklare de observerte kjønnsforskjellene i forekomsten av selvmord.

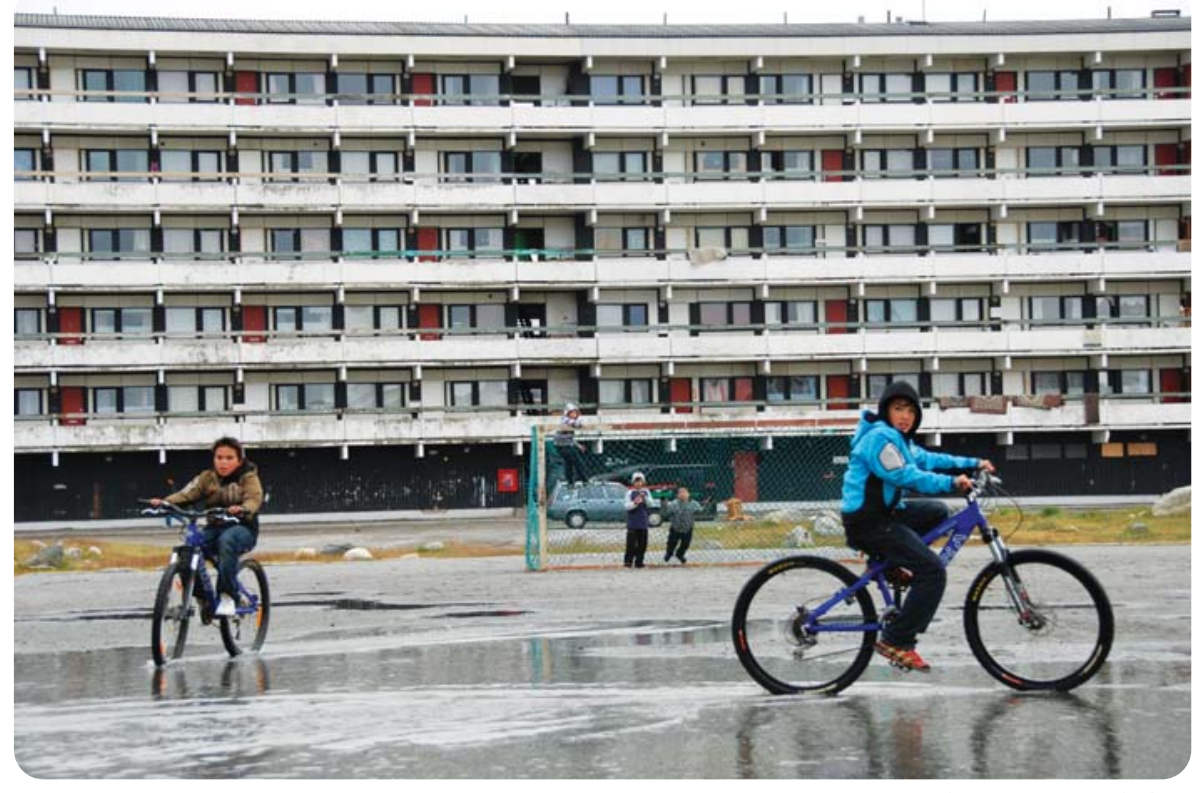

Nuuk. Foto: Anne Silviken 


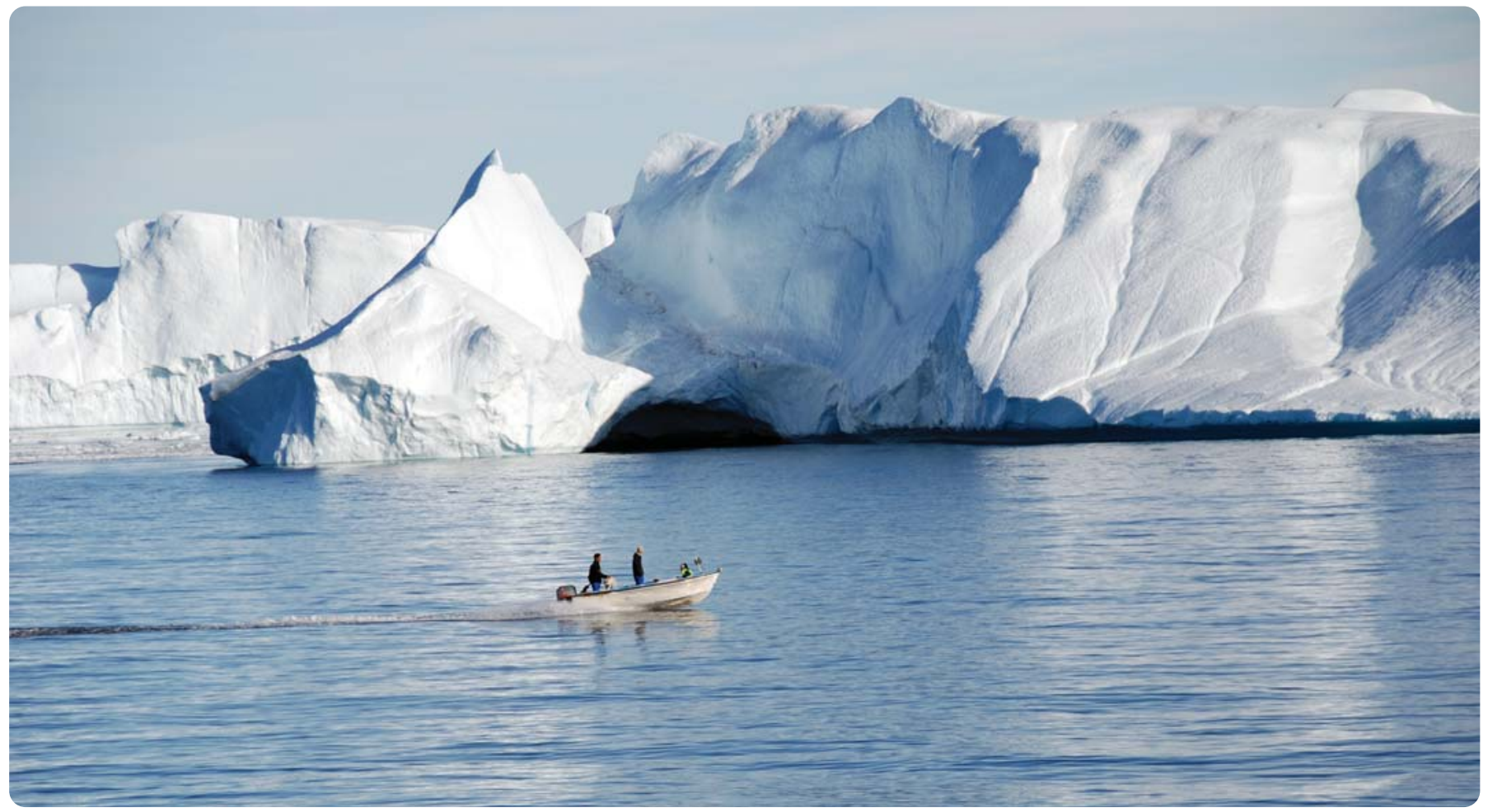

\section{Betydningen av oppdragelsesverdier}

Flere studier har dokumentert betydningen av innflytelsen av foreldre-barnrelasjonen på selvmordsatferd (Beautrais, 2000). Tradisjonell samisk barneoppdragelse har verdier som er tilsvarende dem man finner blant andre urfolk, slik som vektleggingen på uavhengighet, autonomi, hardf $\varnothing$ rhet og fysisk nærhet (Javo et al., 2003). Et interessant fenomen i denne sammenheng er hardførhet, evnen til å være psykisk sterk og være i stand til å tåle stress og frustrasjon - gode egenskaper når man skal overleve i et tøft ytre klima og i næringer som jakt, fangst og reindrift. "Nárrideapmi" (herding) er en samisk barneoppdragelsesteknikk som blir brukt for å forsterke uavhengighet, en form for trening som gjør barnet hardført ved å lære det selvkontroll (Javo et al., 2003). Gjennom "nárrideapmi” utvikler barnet sin verbale evne som hjelper det til å kontrollere sinne, temperamentsutbrudd, sårbarhet, aggresjon og skam (Balto, 1997). Forenklet kan man si at denne teknikken implisitt fostrer forventninger og en kulturell norm som sier at du skal kontrollere følelsene dine, ikke la noen vippe deg av pinnen, samt takle ulike vanskeligheter. Denne oppdragelsesteknikken er ifølge Balto (1997) en effektiv måte å opprettholde tradisjonelle kjønnsroller på. Generelt sagt forventer den kulturelle normen at gutter ikke skal vise følelser eller oppføre seg "feminint". Dessuten vektlegger tradisjonell samisk barneoppdragelse uavhengighet, evnen til å tenke selv og klare seg på egenhånd, med minst mulig hjelp fra andre (Javo et al., 2003). Beskrivelsene av kjønnsrollem $\varnothing$ nsteret for de samiske guttene er sammenfallende med mønsteret man finner blant andre urfolksgrupper. Blant de inuittiske guttene i Nunavuk i Canada fant man for eksempel en forventning om emosjonell selvkontroll og motstand mot å vise og uttrykke problemer, og i tillegg en tendens til å uttrykke vansker gjennom atferdsproblemer og rusmisbruk (Kirmayer et al., 1998). Hvordan kan disse forventningene om selvstendighet og evne til å klare seg selv være med på å forklare de høye selvmordsratene blant guttene?

\section{Autonomi og uavhengighet til hinder for hjelpsøking}

Selv om levekårene har forandret seg betydelig, er idealet om å være en "garra almmái” (en tøff/hardfør mann), som kan overleve i naturen og under ekstreme forhold, fremdeles til stede i samisk kultur (Balto, 1997). Det er ingen tvil om at uavhengighet er nødvendig og adaptivt i et barskt og tøft klima. I kulturer som har gjennomgått fundamentale forandringer, kan imidlertid den tradisjonelle mannsrollen fremstå som statisk og mindre "funksjonell" i dagens samfunn. Borowsky og kollegaer (1999) har hevdet at urfolksgrupper i USA og Alaska som vektlegger mannlig styrke og kontroll kan gi sterke motforestillinger hos unge gutter til å snakke om problemer og å s $\varnothing$ ke n $\varnothing$ dvendig hjelp. Et interessant spørsmål i denne sammenheng blir under hvilke betingelser er det akseptert for gutter å s $\varnothing$ ke hjelp eller å uttrykke sin sårbarhet uten å bli karakterisert som feminine eller "svake"? Sosial støtte er forventet å ha en direkte innvirkning på ungdommers utvikling og velvære, og i tillegg kan familie og jevnaldrende utgjøre en viktig buffer mot 
de negative konsekvensene av belastende livshendelser (Aro, Hanninen \& Paronen, 1989; Ystgaard, Tambs \& Dalgard, 1999). Hvis den kulturelle normen forteller unge urfolksgutter at de ikke skal kommunisere problemene sine til andre, hvilke negative konsekvenser vil ikke dette kunne ha for deres hjelps $\varnothing$ kingsatferd og opplevelse av sosial st $\varnothing$ tte? Samtidig vil en kulturell norm som forteller unge urfolksgutter at de bør klare seg selv uten hjelp fra andre, kunne gi et inntrykk av at selvmordsatferd er et personlig anliggende, som individet skal være i stand til å takle på egen hånd. Selvmordsatferd bør heller betraktes som et samfunnsproblem og ikke som et isolert personlig anliggende. Wexler (2006, s. 2946) har rettet fokus mot viktigheten av en kollektiv bevissthet blant urfolk. Hun hevder at "En forståelse av hvordan kolonisering startet og fremdeles pågår $i$ dag, vil kunne sette samfunnets vansker inn i en historisk kontekst og gi ungdommene begreper for å bedre forstå og håndtere sine opplevelser".

Avslutningsvis, selvmordsproblematikken er uavhengig av befolkningsgruppe en tragedie og et alvorlig samfunnsproblem. De høye selvmordsratene blant urfolksguttene vitner om at de har vært mer sårbare enn jentene under de raske samfunnsmessige endringene som har funnet sted siden 1960-70-tallet. Endringer i kjønnsrollem $\varnothing$ nster sammen med oppdragelsesverdier som om autonomi og hardførhet, kan være faktorer som har betydning for de høye selvmordsratene blant urfolksguttene. De generelt høye selvmordsratene blant urfolk fordrer $\varnothing \mathrm{kt}$ fokus på implementering av selvmordsforebyggende tiltak tilpasset lokal kontekst, kjønn og alder.

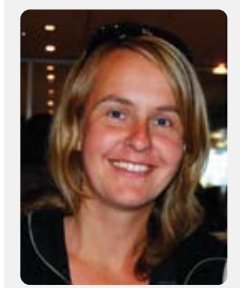

Anne Silviken arbeider som forsker på Senter for samisk helseforskning, med kontorsted Karasjok, Institutt for samfunnsmedisin, Universitetet i Troms $\varnothing$. Hennes doktorgradsarbeid omhandler selvmordsatferd blant samer i Nord-Norge.

Hun jobber i tillegg som psykolog i Samisk ungdomspsykiatrisk team, Samisk nasjonalt kompetansesenter - psykisk helsevern, HelseFinnmark.

\section{Referanser}

Aro, H., Hanninen, V. \& Paronen, O. (1989). Social support, life events and psychosomatics symptoms among 14-16-year-old adolescents. Social Science \& Medicine, 29, 1051-1056.

Balto, A. (1997). Samisk barneoppdragelse i endring. Norge: ad Notam Gyldendal.

Beautrais, A. L. (2000). Risk factors for suicide and attempted suicide among young people.

Australian and New Zealand Journal of Psychiatry, 34, 420-436.

Bille-Brahe, U. (2002). Sociology and suicidal behaviour. In Hawton, K. \& van Heeringen, K. (Eds.), The international handbook of suicide and attempted suicide. (pp 193-207). Chichester: John Wiley \& Sons.

Bjerregaard, P. \& Lynge, I. (2006). Suicide - A challenge in modern Greenland. Archives of Suicide Research, 10, 209 - 220.

Bjerregaard, P., Young, T. K., Dewailly, E. \& Ebbeson, S. O. (2004). Indigenous health in the Arctic: an overview of the circumpolar Inuit population. Scandinavian Journal of Public Health, 32, 390-395.

Boothroyd, L. J., Kirmayer, L. J., Spreng, S., Malus, M. \& Hodgins, S. (2001). Completed suicides among the Inuit of northern Quebec, 1982.

1996: a case-control study. Canadian Medical Association Journal, 165, 749-755.

Borowsky, I. W., Resnick, M. D., Ireland, M. \& Blum, R. W. (1999). Suicide attempts among American Indian and Alaska Native youth: risk and protective factors. Archives of Pediatrics \& Adolescent Medicine, 153, 573-580.

Clarke, V. A., Frankish, C. J. \& Green, L. W. (1997). Understanding suicide among indigenous adolescents: a review using the PRECEDE model. Journal of the International Society for Child and Adolescent Injury Prevention, 3, 126-134.

Davenport, J. A., \& Davenport, J. (1987). Native American suicide: a Durkheimian analysis.

The Journal of Contemporary Social Work, 11, 533-539.

Diekstra, R. F. (1993). The epidemiology of suicide and parasuicide. Acta Psychiatrica Scandinavica, 371, 9-20. Supplementum.

Hawton, K. (2000). Sex and suicide. Gender differences in suicidal behaviour. British Journal of Psychiatry, 177, 484-485.

Hicks, J. (2007). Selvmord blant grønlandske unge $i$ et historisk og cirkumpolart perspektiv. I Kahlig, W. \& Banerjee, N. (red.). Børn og unge i Grønland : en antologi. Nuuk: MIPI -

Videnscenter om børn og unge, s.264-274.

Hunter, E. (1999). Considering the changing environment of indigenous child development. Australasian Psychiatry, 7, 137-140.

Hunter, E. \& Harvey, D. (2002). Indigenous suicide in Australia, New Zealand, Canada, and the United States. Emergency Medicine, 14, 14-23.
Hunter, E. \& Milroy, H. (2006). Aboriginal and Torres Strait Islander suicide in context. Archives of Suicide Research,10, 141-157.

Javo, C., Alapack, R., Heyerdahl, S. \& Ronning, J. A. (2003). Parental values and ethnic identity in indigenous Sami families: a qualitative study. Family Process, 42, 151-164.

Kirmayer, L. J., Brass, G. M., Tait, C. L. (2000). The mental health of Aboriginal peoples: transformations of identity and community.

The Canadian Journal of Psychiatry, 45, 607-616. Kirmayer, L. J., Boothroyd, L. J. \& Hodgins, S. (1998). Attempted suicide among Inuit youth: psychosocial correlates and implications for prevention. Canadian Journal of Psychiatry, 43, 816-822.

Kirmayer, L. J., Malus, M. \& Boothroyd, L. J. (1996). Suicide attempts among Inuit youth: a community survey of prevalence and risk factors. Acta Psychiatrica Scandinavica, 94, 8-17.

Kirmayer, L. J. (1994). Suicide among Canadian aboriginal peoples. Transcultural Psychiatric Research Review, 31, 3-57.

Leenaars, A. A. (2006). Suicide among indigenous peoples: introduction and call to action. Archives of Suicide Research, 10, 103-115.

Sigurdson, E., Staley, D., Matas, M., Hildahl, K. $\&$ Squair, K. (1994). A five year review of youth suicide in Manitoba. Canadian Journal of Psychiatry 39, 397-403.

Silviken, A., Haldorsen, T. \& Kvernmo, S. (2006). Suicide among indigenous Sami in Arctic Norway, 1970-1998. European Journal of Epidemiology, 21, 707-713.

Wallace, L., Calhoun, A., Powell, K., O'Neill, J. $\&$ James, S. (1996). Homicide and suicide among Native Americans 1979-1992. Atlanta: CDC, National Center for Injury Prevention and Control. www.cdc.gov/ncipc/pub-res/natam.htm\#PDF

Wexler, L. M. (2006). Inupiat youth suicide and culture loss: Changing community conversations for prevention. Social Science \& Medicine, 63, 2938-2948.

Young, T. K. (1994). The health of native Americans: towards a biocultural epidemiology. New York: Oxford University Press.

Ystgaard, M., Tambs, K. \& Dalgard, O. S. (1999). Life stress, social support and psychological distress in late adolescence: a longitudinal study. Social Psychiatry and Psychiatric Epidemiology, 34, 12-19. 